\title{
Preparation and Antibacterial Properties of Substituted 1,2,4-Triazoles
}

\author{
Ionuţ Ledeţi, ${ }^{1}$ Vasile Bercean, ${ }^{2}$ Anda Alexa, ${ }^{3}$ Codruţa Şoica, ${ }^{1}$ \\ Lenuţa-Maria Şuta, ${ }^{1}$ Cristina Dehelean, ${ }^{1}$ Cristina Trandafirescu, ${ }^{1}$ \\ Delia Muntean, ${ }^{3}$ Monica Licker, ${ }^{3}$ and Adriana Fuliaş ${ }^{1}$ \\ ${ }^{1}$ Faculty of Pharmacy, University of Medicine and Pharmacy "Victor Babeş", 2 Eftimie Murgu Square, 300041 Timişoara, Romania \\ ${ }^{2}$ Faculty of Industrial Chemistry and Environmental Engineering, Politehnica University Timişoara, 6 Carol Telbisz, \\ 300001 Timişoara, Romania \\ ${ }^{3}$ Faculty of Medicine, University of Medicine and Pharmacy "Victor Babeş", 2 Eftimie Murgu Square, 300041 Timişoara, Romania
}

Correspondence should be addressed to Vasile Bercean; vbercean@gmail.com

Received 14 January 2015; Revised 22 February 2015; Accepted 22 February 2015

Academic Editor: Teodorico C. Ramalho

Copyright (C) 2015 Ionuţ Ledeți et al. This is an open access article distributed under the Creative Commons Attribution License, which permits unrestricted use, distribution, and reproduction in any medium, provided the original work is properly cited.

\begin{abstract}
Background. Both 1,2,3- and 1,2,4-triazoles are nowadays incorporated in numerous antibacterial pharmaceutical formulations. Aim. Our study aimed to prepare three substituted 1,2,4-triazoles and to evaluate their antibacterial properties. Materials and Methods. One disubstituted and two trisubstituted 1,2,4-triazoles were prepared and characterised by physical and spectroscopic properties (melting point, FTIR, NMR, and GC-MS). The antibacterial properties were studied against three bacterial strains: Staphylococcus aureus (ATCC 25923), Escherichia coli (ATCC 25922), and Pseudomonas aeruginosa (ATCC 27853), by the agar disk diffusion method and the dilution method with MIC (minimal inhibitory concentration) determination. Results. The spectroscopic characterization of compounds and the working protocol for the synthesis of the triazolic derivatives are described. The compounds were obtained with $15-43 \%$ yields and with high purities, confirmed by the NMR analysis. The evaluation of biological activities showed that the compounds act as antibacterial agents against Staphylococcus aureus (ATCC 25923), while being inactive against Escherichia coli (ATCC 25922) and Pseudomonas aeruginosa (ATCC 27853). Conclusions. Our results indicate that compounds containing 1,2,4-triazolic moiety have great potential in developing a wide variety of new antibacterial formulations.
\end{abstract}

\section{Introduction}

Triazolic nucleus is nowadays considered an important moiety in the design and synthesis of bioactive compounds that are associated with numerous biological activities [1] such as antibacterial, antifungal [2], anti-inflammatory [3], anticonvulsant [4], anti-HIV [5], antineoplastic, and antiproliferative [6-13]. Additionally, there are review studies that indicate the fact that 1,2,4-triazoles occupy a distinctive place in the field of medicinal and pharmaceutical chemistry $[14,15]$, as well as in industry [16]. Also, synthesis and complete characterization by both spectroscopic and thermal techniques were reported in literature for numerous derivatives bearing 1,2,4triazole moieties [17-20].
According to this, we set our goal in the synthesis, characterization (physical and spectroscopic properties, melting point, FTIR, NMR, and GC-MS), and evaluation of biological activity of three substitutes triazoles (1-3) against Staphylococcus aureus (ATCC 25923), Escherichia coli (ATCC 25922), and Pseudomonas aeruginosa (ATCC 27853).

\section{Materials and Methods}

2.1. Chemistry. The reagents were commercial products of analytical purity (Chimopar, Merck, Fluka) and used as received. Melting points were determined on a Böetius PHMK (Veb Analytik, Dresden, Germany) instrument (the values are uncorrected), and thin-layer chromatography 


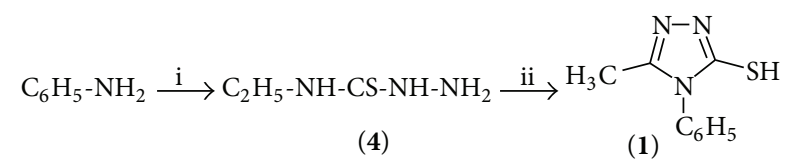

$\mathrm{i}=$ (1) $\mathrm{CS}_{2} / \mathrm{KOH} / \mathrm{C}_{2} \mathrm{H}_{5} \mathrm{OH}-\mathrm{HO} \sim 20^{\circ} \mathrm{C}$; (2) $\mathrm{ClCH}_{2} \mathrm{COONa} / \mathrm{H}_{2} \mathrm{O} \sim 20^{\circ} \mathrm{C}$; (3) $\mathrm{H}_{2} \mathrm{~N}-\mathrm{NH}_{2} \cdot \mathrm{H}_{2} \mathrm{O}$ reflux

ii = (1) $\mathrm{CH}_{3} \mathrm{COOC}_{2} \mathrm{H}_{5}$ (b)/ $\mathrm{CH}_{3} \mathrm{ONa} / \mathrm{CH}_{3} \mathrm{OH}$ reflux; (2) $\mathrm{HCl}$ dil

SCHEme 1: The synthesis of 4H-3-mercapto-5-methyl-4-phenyl-1,2,4-triazole (1).

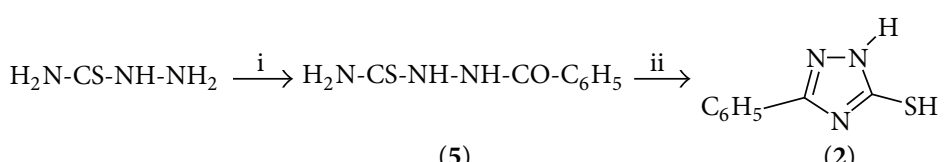

(5)

(2)

$\mathrm{i}=\mathrm{C}_{6} \mathrm{H}_{5}-\mathrm{COCl} / \mathrm{Py} / \mathrm{DMF} \sim 20^{\circ} \mathrm{C}$; ii = (1) NaOH/ $\mathrm{H}_{2} \mathrm{O}-\mathrm{C}_{2} \mathrm{H}_{5} \mathrm{OH}$ reflux; (2) $\mathrm{HCl}$ dil.

Scheme 2: The synthesis of $1 H$-5-mercapto-3-phenyl-1,2,4-triazole (2).

(TLC) was carried out on silica gel-coated plates 60 F254 Merck using hexane : ethyl acetate $1: 1(\mathrm{v} / \mathrm{v})$ as eluant.

FTIR spectra were recorded in $\mathrm{KBr}$ pellet using a Specac Pellet Press (Specac Ltd., Kent, UK) on a Jasco FT/IR-410 spectrophotometer (Jasco Analytical Instruments, Easton, USA) using the following abbreviation for the aspect/intensities of the bands: br: broad; s: strong; $\mathrm{m}$ : medium; w: weak.

${ }^{1} \mathrm{H}-\mathrm{NMR}$ and ${ }^{13} \mathrm{C}-\mathrm{NMR}$ spectra were recorded on a Bruker Avance AC200 spectrometer (Bruker Biospin International, Ag, Aegeristrasse, Switzerland) in DMSO- $d_{6}$, using TMS as reference; chemical shifts are reported in ppm and the coupling constants in Hz. The multiplicity of the signal and the aspect of the band are abbreviated as follows: br: broad; s: singlet; d: doublet; m: multiplet.

Mass spectra GC-MS were obtained using an Agilent G1701DA apparatus (Agilent Technologies, Inc., Santa Clara, USA) using methanol as carrier solvent.

2.2. In Vitro Antibacterial Activity. The compounds were screened for their antimicrobial activity against three bacterial strains: Staphylococcus aureus (ATCC 25923), Escherichia coli (ATCC 25922), and Pseudomonas aeruginosa (ATCC 27853), by the agar disk diffusion method and the dilution method with MIC (minimal inhibitory concentration) determination.

2.3. Experimental Protocols for the Synthesis of Bioactive Compounds (1-3). The synthesis of 4H-3-mercapto-5methyl-4-phenyl-1,2,4-triazole (1) was carried out according to a described protocol [21, 22] by heating 4-phenylthiosemicarbazide (4) with ethyl acetate and sodium methoxide in methanol under reflux, followed by neutralization. The synthesis of 4-phenylthiosemicarbazide was however realized in a single-step reaction, by treating aniline with $\mathrm{CS}_{2}$ and alcoholic $\mathrm{KOH}$ solution, sodium chloroacetate, and hydrazine hydrate under reflux (Scheme 1) [11].

Compound 1, 4H-3-mercapto-5-methyl-4-phenyl-1,2,4triazole, was obtained as a white powder (yield 21\%), TLC one spot, m.p. $214-215^{\circ} \mathrm{C}$. FTIR $\left(\mathrm{KBr}, \mathrm{cm}^{-1}\right)$ : 3301m; 3158m; 3097m; 3054m; 2908m; 1579m; 1498s; 1326s; 1288m; 1018w; 771w; 692m; ${ }^{1} \mathrm{H}-\mathrm{NMR} \delta_{\mathrm{H}}$ (DMSO- $\left.d_{6}, 200 \mathrm{MHz}\right): 13.50$ (br.s, $1 \mathrm{H},-\mathrm{SH}) ; 7.30-7.65$ (m, 5H, $\left.-\mathrm{C}_{6} \mathrm{H}_{5}\right) ; 2.08$ (s, 3H, $-\mathrm{CH}_{3}$ ).

1H-5-Mercapto-3-phenyl-1,2,4-triazole (2) was obtained by benzoylation of thiosemicarbazide with benzoyl chlorides, followed by cyclisation of crude 1-benzoyl-thiosemicarbazide (5) with $\mathrm{NaOH}$ in aqueous-alcoholic medium, using a method previously used in our research group (Scheme 2) [23].

Compound 2, $1 H$-5-mercapto-3-phenyl-1,2,4-triazole, was obtained as a white powder (yield 43\%), TLC one spot, m.p. $242-247^{\circ} \mathrm{C}$ (lit. $254-256^{\circ} \mathrm{C}$ [24]). FTIR $\left(\mathrm{KBr}, \mathrm{cm}^{-1}\right)$ : 3450m; 3421m; 1630m; 1610m; 1563m; 1289m; 1080w; 776w; ${ }^{1} \mathrm{H}-\mathrm{NMR} \delta_{\mathrm{H}}\left(\mathrm{DMSO}-d_{6}, 200 \mathrm{MHz}\right): 13.87(\mathrm{~s}, 1 \mathrm{H}, \mathrm{SH}) ; 13.70$ (s, $1 \mathrm{H}, \mathrm{NH}) ; 7.47-7.95(\mathrm{~m}, 5 \mathrm{H},-\mathrm{Ph}) ;{ }^{13} \mathrm{C}-\mathrm{RMN} \delta_{\mathrm{C}}\left(\mathrm{DMSO}-d_{6}\right.$, $100 \mathrm{MHz}): 172.20(\mathrm{C}-\mathrm{S}) ; 155.41(\mathrm{C}=\mathrm{N}) ; 135.84\left(1^{\prime}-\mathrm{C}\right) ; 134.33$ $\left(4^{\prime}-\mathrm{C}\right) ; 130.86\left(3^{\prime}-\mathrm{C}, 5^{\prime}-\mathrm{C}\right) ; 130.65\left(2^{\prime}-\mathrm{C}, 6^{\prime}-\mathrm{C}\right)$.

4H-4-Amino-5-(4-pyridyl)-3-mercapto-1,2,4-triazole (3) was obtained using as starting compound, the hydrazide of isonicotinic acid (6), using a previously described method by us (Scheme 3) [25].

Compound 3, 4H-4-amino-5-(4-pyridyl)-3-mercapto1,2,4-triazole, was obtained as a white powder (yield 15\%), TLC one spot, m.p. $204-206^{\circ}$ C. GC-MS (M/z): purity 99\%; 193(M; 100\%), 105(Py-C=NH $\left.{ }^{+}, 27 \%\right)$; FTIR $\left(\mathrm{KBr}, \mathrm{cm}^{-1}\right)$ : $3272 \mathrm{~s} ; 3162 \mathrm{~s} ; 1608 \mathrm{~m} ; 1318 \mathrm{~m} ; 826 \mathrm{~m} ; 736 \mathrm{w} ;{ }^{1} \mathrm{H}-\mathrm{RMN} \delta_{\mathrm{H}}$ (DMSO- $\left.d_{6}, 200 \mathrm{MHz}\right): 14.18(\mathrm{~s}, 1 \mathrm{H},-\mathrm{NH}) ; 8.77$ (d, $2 \mathrm{H}$, $\left.\mathrm{J}_{3^{\prime}-\mathrm{H}, 5^{\prime} \mathrm{H}}=5.6 \mathrm{~Hz}, 3^{\prime} \mathrm{H}, 5^{\prime} \mathrm{H}\right) ; 8.04\left(\mathrm{~d}, 2 \mathrm{H}, \mathrm{J}_{2^{\prime}-\mathrm{H}, 6^{\prime} \mathrm{H}}=5.6 \mathrm{~Hz}\right.$, $2^{\prime} \mathrm{H}, 6^{\prime} \mathrm{H}$ ), 5.87 (s.broad, $2 \mathrm{H},-\mathrm{NH}_{2}$ ); ${ }^{13} \mathrm{C}-\mathrm{RMN} \delta_{\mathrm{C}}$ (DMSO$\left.d_{6}, 100 \mathrm{MHz}\right): 167.6(5-\mathrm{C}) ; 150.07\left(3^{\prime} \mathrm{C}, 5^{\prime} \mathrm{C}\right) ; 147.28$ (3-C); 132.8 $\left(1^{\prime} \mathrm{C}\right) ; 121.48\left(2^{\prime} \mathrm{C}, 6^{\prime} \mathrm{C}\right)$.

2.4. Disk Diffusion Method. The antimicrobial activity of the compounds was evaluated according to the guidelines of the National Committee for Clinical Laboratory Standards (NCCLS, 1997) using agar disk diffusion method [26].

NCCLS recommends a bacterial suspension with a density equal to a $0.5 \mathrm{McF}$ arland (which gives a final bacterial concentration of $1-2 \cdot 10^{8} \mathrm{CFU} / \mathrm{mL}$ ). The Mueller-Hinton agar 


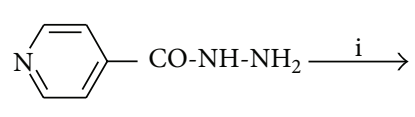

(6)

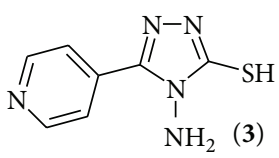

$\mathrm{NH}_{2}$ (3)

$\mathrm{i}=(1) \mathrm{CS}_{2} / \mathrm{KOH} / \mathrm{H}_{2} \mathrm{O}-\mathrm{C}_{2} \mathrm{H}_{5} \mathrm{OH}$; (2) $\mathrm{H}_{2} \mathrm{~N}-\mathrm{NH}_{2} \cdot \mathrm{H}_{2} \mathrm{O} 2 \mathrm{~h}$ r.t; (3) reflux $4 \mathrm{~h}$; (4) $\mathrm{HCl}$ dil

Scheme 3: The synthesis of 4H-4-amino-5-(4-pyridyl)-3-mercapto-1,2,4-triazole (3).

TABLE 1: Antimicrobial activity of compounds.

\begin{tabular}{|c|c|c|c|c|}
\hline \multirow{2}{*}{ Compounds } & \multicolumn{4}{|c|}{ Zone of inhibition $(\mathrm{mm}) / \mathrm{MIC}(\mu \mathrm{g} / \mathrm{mL})$} \\
\hline & \multicolumn{2}{|c|}{ S. aureus ATCC 25923} & E. coli & P. aeruginosa \\
\hline 1 & $\begin{array}{c}0.5 \%-14 \mathrm{~mm} \\
1 \%-17 \mathrm{~mm}\end{array}$ & $40 \mu \mathrm{g} / \mathrm{mL}$ & - & - \\
\hline 2 & $1 \%-12 \mathrm{~mm}$ & $25 \mu \mathrm{g} / \mathrm{mL}$ & - & - \\
\hline 3 & $1 \%-11 \mathrm{~mm}$ & $25 \mu \mathrm{g} / \mathrm{mL}$ & - & - \\
\hline Gentamicin $(10 \mu \mathrm{g} /$ disk $)$ & \multicolumn{2}{|c|}{$20 \mathrm{~mm}$} & $20 \mathrm{~mm}$ & $19 \mathrm{~mm}$ \\
\hline
\end{tabular}

plates were inoculated with bacterial suspension using a sterile cotton swab.

A series of solutions of the tested compounds were prepared in DMSO, with a concentration of $0.01 \%, 0.1 \%$, $0.5 \%$, and $1 \%$, respectively. Within $15 \mathrm{~min}$ after the plates were inoculated, sterile Whatman number 1 filter paper disks $(6 \mathrm{~mm}$ in diameter) impregnated with the solutions in DMSO of the tested compounds $(20 \mu \mathrm{L}$ solution/disk, corresponding to $2,20,100$, and $200 \mu \mathrm{g}$ compound/disk, resp., for the four solutions prepared with each compound) were distributed evenly on the surface, with at least $25 \mathrm{~mm}$ (center to center) between them. Disks with gentamicin $(10 \mu \mathrm{g})$, supplied by Bio-Rad, were used as positive control for the antimicrobial activity. For negative control we used a paper disk impregnated with dimethylsulfoxide (DMSO).

Plates inoculated with the bacterial suspensions were incubated at $37^{\circ} \mathrm{C}$ for $24 \mathrm{~h}$. The inhibition zone diameters were measured in millimeters, using a ruler. For all the bacterial strains the disk diffusion tests were performed in triplicate and the average reading was taken into account.

2.5. Dilution Method. The MIC values were determined only for the active compounds, with a zone of inhibition $>10 \mathrm{~mm}$. The MIC values were evaluated in the range of $1.56-50 \mu \mathrm{g} / \mathrm{mL}$.

The MIC $(\mu \mathrm{g} / \mathrm{mL})$ was determined by the binary microdilution method. We prepared stock solutions in DMSO of the tested compounds, at a concentration of $100 \mu \mathrm{g} / \mathrm{mL}$. From these solutions, serial dilutions of the compounds $(50,25$, $12.5,6.25,3.12$, and $1.56 \mu \mathrm{g} / \mathrm{mL}$ ) were prepared and brought, under aseptic conditions, to a final volume of $200 \mu \mathrm{L}$ with nutrient medium. In all tubes $50 \mu \mathrm{L}$ of bacterial suspensions were added, with a density equal to a $0.5 \mathrm{McF}$ arland. All tubes were incubated at $37^{\circ} \mathrm{C}$ for $24 \mathrm{~h}$. The MIC was recorded as the minimum concentration of the compound which inhibited the visible growth of the tested microorganisms. For a negative control $50 \mu \mathrm{L}$ of DMSO was introduced in a tube with $50 \mu \mathrm{L}$ of bacterial suspension and $100 \mu \mathrm{L}$ of nutrient medium.

We performed triplicate tests and, from all the tubes used for MICs reading, cultures on Columbia agar supplemented with $5 \%$ sheep blood were performed in order to verify the results; no bacterial growth was recorded in the presence of the tested solution to which MIC was attributed.

\section{Results and Discussion}

The synthesis of heterocyclic derivatives (1-3) was performed according to indications mentioned in literature. The compounds were obtained with moderate yields (15-43\%) but with high purity, fact confirmed by TLC analysis and evaluation of melting interval. The formation of triazolic derivatives was proven by FTIR and NMR analysis, as well by mass spectrometry for the compound (3).

The results of the antimicrobial evaluation are presented in Table 1.

The synthesized and evaluated derivatives with triazolic structure were tested for antibacterial activity against three bacterial strains by means of the disk diffusion method. The results presented in Table 1 reveal that only two compounds may act as anti-infective agents, inhibiting the growth of $S$. aureus ATCC 25923 at concentrations within the range of $25-40 \mu \mathrm{g} / \mathrm{mL}$. It is worth mentioning that both compounds are active against Gram-positive bacteria ( $S$. aureus) while no activity was present against Gram-negative bacteria ( $E$. coli, $P$. aeruginosa); these results demonstrate a specific antimicrobial activity against Gram-positive bacterial infections. Gentamicin is a powerful broad-spectrum antibiotic, largely used in clinical practice, usually in association with $\beta$-lactam antibiotics, for the treatment of a wide range of bacterial infections; in this paper, it served as reference for the antimicrobial potency of the tested compounds. Both active substances, as showed in Table 1, produced an inhibition zone 
with a diameter between 11 and $17 \mathrm{~cm}$ at an MIC of 25$40 \mu \mathrm{g} / \mathrm{mL}$. The results are comparable to the ones revealed in case of gentamicin $(20 \mathrm{~mm})$, demonstrating the possibility of future therapeutical use of the two compounds as potential antibacterial agents.

\section{Conflict of Interests}

The authors declare that there is no conflict of interests regarding the publication of this paper.

\section{Acknowledgment}

This work was supported by a grant from the University of Medicine and Pharmacy "Victor Babeş" Timişoara (Grant IIC2-TC-2014-16498-08 to Ionuţ Ledeţi).

\section{References}

[1] S. H. Sumrra and Z. H. Chohan, "Metal based new triazoles: their synthesis, characterization and antibacterial/antifungal activities," Spectrochimica Acta Part A: Molecular and Biomolecular Spectroscopy, vol. 98, pp. 53-61, 2012.

[2] P. Zoumpoulakis, C. Camoutsis, G. Pairas et al., "Synthesis of novel sulfonamide-1,2,4-triazoles, 1,3,4-thiadiazoles and 1,3,4oxadiazoles, as potential antibacterial and antifungal agents. Biological evaluation and conformational analysis studies," Bioorganic and Medicinal Chemistry, vol. 20, no. 4, pp. 15691583, 2012.

[3] E. S. Al-Aabdullah, H. H. Asiri, S. Lahsasni, E. E. Habib, T. M. Ibrahim, and A. A. El-Emam, "Synthesis, antimicrobial, and anti-inflammatory activity, of novel s-substituted and n-substituted 5-(1-adamantyl)-1,2,4-triazole-3-thiols," Drug Design, Development and Therapy, vol. 8, pp. 505-517, 2014.

[4] X.-Q. Deng, M.-X. Song, Y. Zheng, and Z.-S. Quan, “Design, synthesis and evaluation of the antidepressant and anticonvulsant activities of triazole-containing quinolinones," European Journal of Medicinal Chemistry, vol. 73, pp. 217-224, 2014.

[5] Z. Li, Y. Cao, P. Zhan et al., "Arylazolylthioacetanilide. Part 11. Design, synthesis and biological evaluation of 1,2,4-triazole thioacetanilide derivatives as novel non-nucleoside HIV-1 reverse transcriptase inhibitors," Medicinal Chemistry, vol. 9, no. 7, pp. 968-973, 2013.

[6] G. Celik, P. Khloya, D. Vullo, C. T. Supuran, and P. K. Sharma, "Benzenesulfonamide bearing 1,2,4-triazole scaffolds as potent inhibitors of tumor associated carbonic anhydrase isoforms hCA IX and hCA XII," Bioorganic and Medicinal Chemistry, vol. 22, no. 6, pp. 1873-1882, 2014.

[7] Ł. Popiołek, J. Rzymowska, U. Kosikowska, A. Hordyjewska, M. Wujec, and A. Malm, "Synthesis, antiproliferative and antimicrobial activity of new Mannich bases bearing 1,2,4triazole moiety," Journal of Enzyme Inhibition and Medicinal Chemistry, vol. 29, no. 6, pp. 786-795, 2014.

[8] H. N. Nagesh, N. Suresh, G. V. S. B. Prakash, S. Gupta, J. V. Rao, and K. V. G. C. Sekhar, "Synthesis and biological evaluation of novel phenanthridinyl piperazine triazoles via click chemistry as anti-proliferative agents," Medicinal Chemistry Research, vol. 24, no. 2, pp. 523-532, 2015.

[9] N. Ahmed, N. K. Konduru, S. Ahmad, and M. Owais, "Design, synthesis and antiproliferative activity of functionalized flavone-triazole-tetrahydropyran conjugates against human cancer cell lines," European Journal of Medicinal Chemistry, vol. 82, pp. 552-564, 2014.

[10] G. Revelant, C. Gadais, V. Mathieu, G. Kirsch, and S. Hesse, "Synthesis and antiproliferative studies of 5-aryl-2-(3-thienylamino)-1,3,4- thiadiazoles," Bioorganic and Medicinal Chemistry Letters, vol. 24, no. 12, pp. 2724-2727, 2014.

[11] M. W. Pertino, V. Verdugo, C. Theoduloz, and G. SchmedaHirschmann, "Synthesis and antiproliferative activity of some novel triazole derivatives from dehydroabietic acid," Molecules, vol. 19, no. 2, pp. 2523-2535, 2014.

[12] B. N. P. Kumar, K. N. Mohana, and L. Mallesha, "Synthesis and antiproliferative activity of some new fluorinated Schiff bases derived from 1,2,4-triazoles," Journal of Fluorine Chemistry, vol. 156, pp. 15-20, 2013.

[13] M. Abdel-Aziz, G. E.-D. A. A. Abuo-Rahma, E. A. M. Beshr, and T. F. S. Ali, "New nitric oxide donating 1,2,4-triazole/oxime hybrids: synthesis, investigation of anti-inflammatory, ulceroginic liability and antiproliferative activities," Bioorganic and Medicinal Chemistry, vol. 21, no. 13, pp. 3839-3849, 2013.

[14] S. Maddila, R. Pagadala, and S. B. Jonnalagadda, "1,2,4Triazoles: a review of synthetic approaches and the biological activity," Letters in Organic Chemistry, vol. 10, no. 10, pp. 693714, 2013.

[15] J. Sharma, S. Ahmad, and A. M. Shamsher, "Bioactive Triazoles: a potential review," Journal of Chemical and Pharmaceutical Research, vol. 4, no. 12, pp. 5157-5164, 2012.

[16] M. M. Antonijevic and M. B. Petrovic, "Copper corrosion inhibitors. A review," International Journal of Electrochemical Science, vol. 3, no. 1, pp. 1-28, 2008.

[17] L. Calu, M. Badea, D. Falcescu, D. Duca, D. Marinescu, and R. Olar, "Thermal study on complexes with Schiff base derived from 1,2,4-triazole as potential antimicrobial agents," Journal of Thermal Analysis and Calorimetry, vol. 111, no. 3, pp. 1725-1730, 2013.

[18] M. Badea, L. Calu, M. C. Chifiriuc et al., "Thermal behaviour of some novel antimicrobials based on complexes with a Schiff base bearing 1,2,4-triazole pharmacophore," Journal of Thermal Analysis and Calorimetry, vol. 118, no. 2, pp. 1145-1157, 2014.

[19] X. J. Du, X. D. Li, M. S. Zou, R. J. Yang, and S. P. Pang, “Thermal kinetic study of 1-amino-1,2,3-triazolium nitrate," Journal of Thermal Analysis and Calorimetry, vol. 115, no. 2, pp. 1195-1203, 2014.

[20] I. Ledeţi, A. Fuliaş, G. Vlase, T. Vlase, V. Bercean, and N. Doca, "Thermal behaviour and kinetic study of some triazoles as potential anti-inflammatory agents," Journal of Thermal Analysis and Calorimetry, vol. 114, no. 3, pp. 1295-1305, 2013.

[21] Y. Lin, S. R. Petty, F. M. Lovell, N. A. Perkinson, and S. A. Lang Jr., "The synthesis of 4-substituted-4H-1,2,4-triazole-3thiols and 3-methylthio-4-substituted-4H,2,4-triazoles," Journal of Heterocyclic Chemistry, vol. 17, pp. 1077-1080, 1980.

[22] M. Nutiu, V. Bercean, and M. Birau, "Synthesis of some 4-arylthiosemicarbazides," Annals of West University of Timişoara, Series of Chemistry, vol. 5, pp. 7-10, 1996.

[23] V. Bercean, V. Badea, E. Sisu, B. Laura, and C. Csunderlik, "Symplified method for obtaining 3-aryl-5-mercapto-1,2,4-triazoles," Revista de Chimie, vol. 54, pp. 368-369, 2003.

[24] E. Hoggarth, "Compounds related to thiosemicarbazide. Part II. 1- benzoylthiosemicarbazides," Journal of the Chemical Society, pp. 1163-1167, 1949. 
[25] A.-A. Creangǎ, V.-N. Bercean, V. Badea et al., "Comparative study for the synthesis of some 5-(2-, 3-, 4-pyridyl) substituted4H-4-amino-3-mercapto-1,2,4-triazoles," Revista de Chimie, vol. 61, no. 12, pp. 1169-1172, 2010.

[26] National Committee for Clinical Laboratory Standards, Performance Standards for Antimicrobial Disk Susceptibility Tests, Approved Standard M2-A6, National Committee for Clinical Laboratory Standards, Wayne, Pa, USA, 1997. 

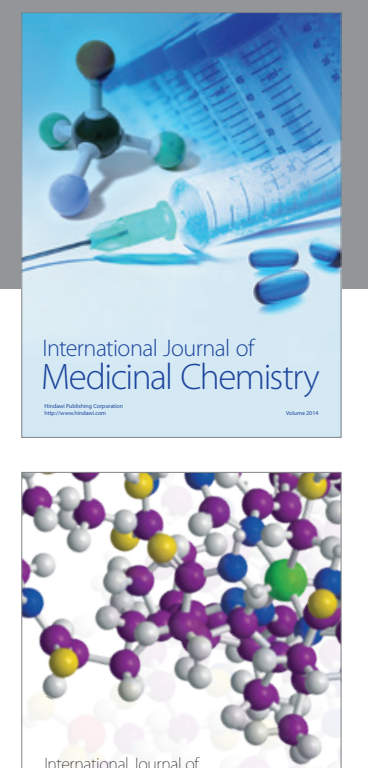

\section{Carbohydrate} Chemistry

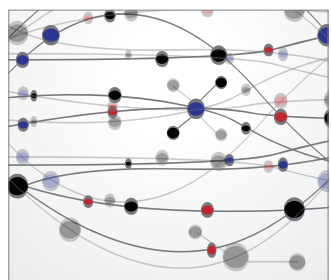

The Scientific World Journal
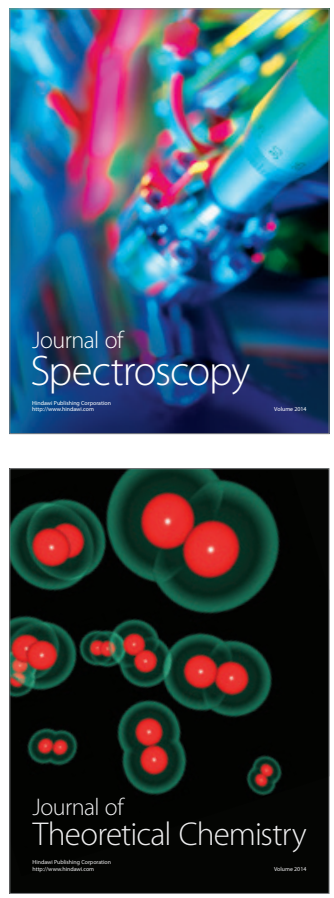
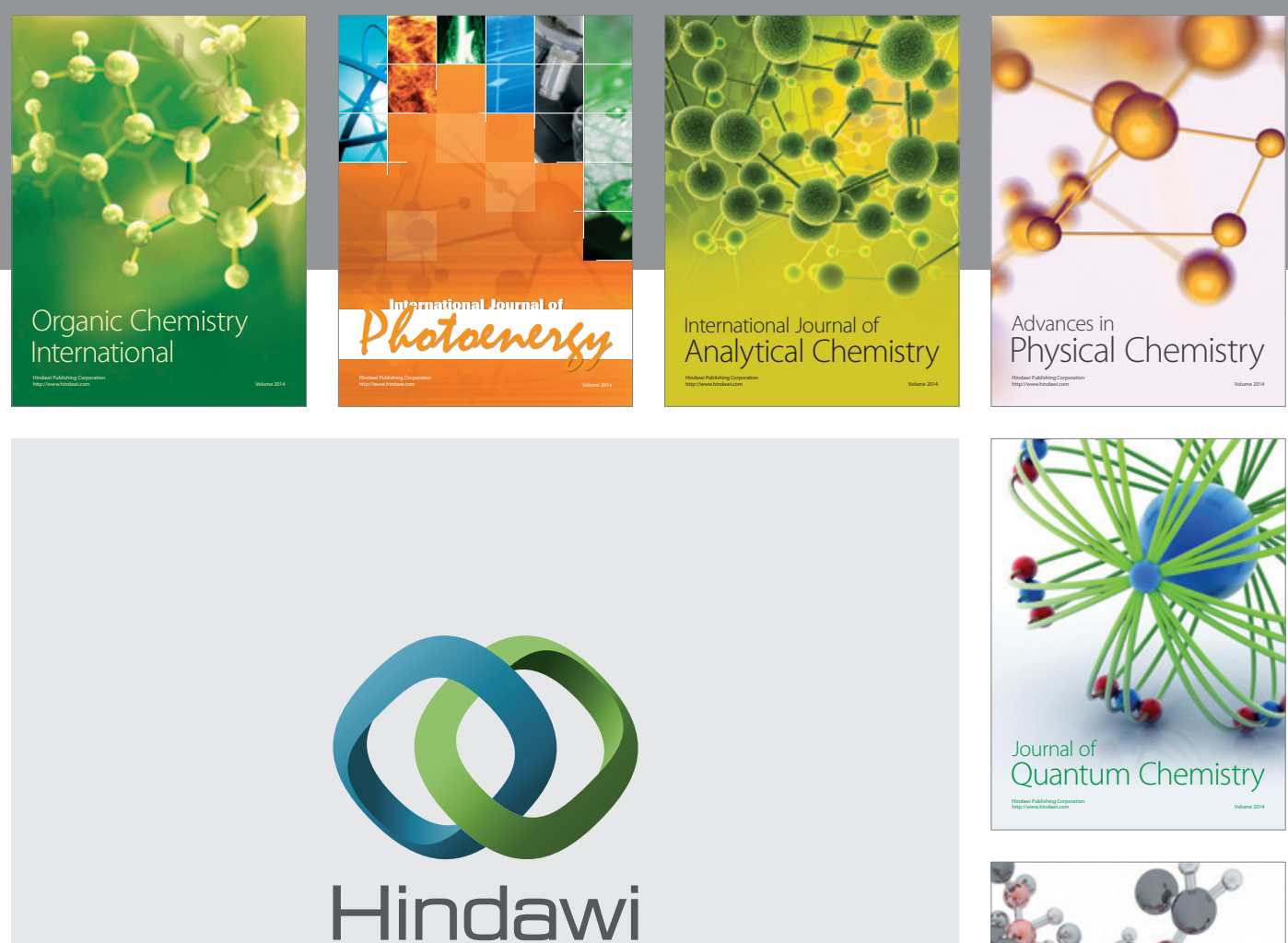

Submit your manuscripts at

http://www.hindawi.com

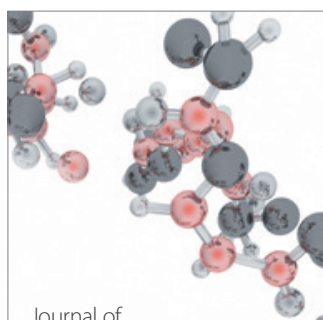

Analytical Methods

in Chemistry

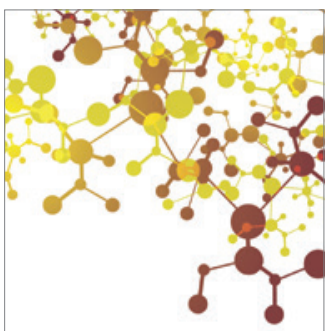

Journal of

Applied Chemistry

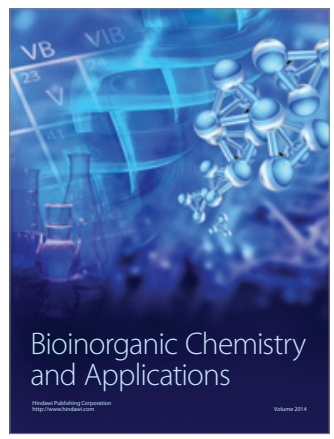

Inorganic Chemistry
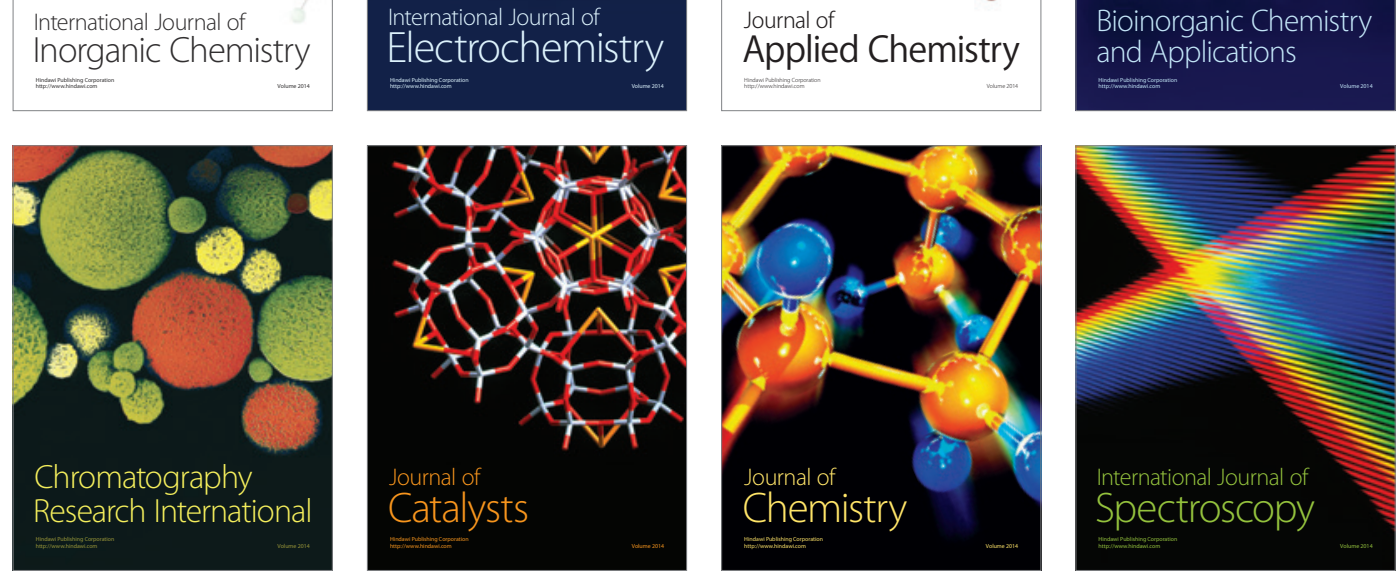